\title{
General managerial skills and corporate social responsibility
}

\author{
Jie Chen \\ Leeds University Business School, University of Leeds \\ Maurice Keyworth Building, Leeds LS2 9JT, UK \\ J.Chen3@leeds.ac.uk \\ Xicheng Liu \\ School of Management, Swansea University \\ Bay Campus, Fabian Way, Swansea, United Kingdom, SA1 8EN \\ x.liu@swansea.ac.uk \\ Wei Song* \\ Southampton Business School, University of Southampton \\ Highfield, Southampton SO17 1BJ, UK \\ Songwei.dunelm@gmail.com \\ Si Zhou \\ School of Economics, Shanghai University, \\ No.99, Shangda Road, Shanghai, 200444, P.R. China. \\ Szhou@shu.edu.cn
}

This version: July 2019

${ }^{*}$ Corresponding author. 


\title{
General managerial skills and corporate social responsibility
}

\begin{abstract}
We show that a CEO's general managerial skills are negatively related to the level of corporate social responsibility (CSR) undertaken by the firm. This finding is robust to alternative measures of CSR and alternative econometric specifications. The negative effect of general managerial skills on CSR persists when we attempt to address potential endogeneity concerns by employing propensity score matching and an instrumental variables approach. Further, supplementary analysis reveals that this negative effect is stronger in tight labor markets and in firms where shareholders are more short term oriented, consistent with the notion that the broader set of outside options available to generalist chief executive officers acts as a labor market mechanism that makes them less concerned about the firm's long-term prosperity and thus more reluctant to commit to CSR.
\end{abstract}

JEL classification: G32; G34; J24; M14

Keywords: Corporate social responsibility; general human capital; market for executives 


\section{Introduction}

Corporate social responsibility (CSR) refers to management's obligation to make decisions beyond legal requirements that are desirable in terms of society's values and objectives (Mosley et al., 1996). The literature suggests that the establishment of a CSR strategy that integrates social, environmental, ethical, and consumer concerns into business operations has become a crucial component of a firm's long-term sustainability and competiveness (McWilliams and Siegel, 2001; Bénabou and Tirole, 2010; Kitzmueller and Shimshack, 2012; Ferrell et al., 2016; Liang and Renneboog, 2017). Thus, understanding the factors that determine a firm's commitment to CSR activity is clearly valuable and pertinent to both academics and practitioners. Several recent studies show that heterogeneity in CEO characteristics or personal traits such as altruism, confidence, and materialism matter for corporate policies related to CSR (Borghesi et al., 2014; Davidson et al., 2016; McCarthy et al., 2017). In this paper, we extend this line of inquiry by examining whether the composition of a CEO's managerial skills affects the level of CSR undertaken by the firm.

Becker's (1962) seminal work on human capital theory distinguished between two types of managerial skills, including general skills, which are transferrable across firms or industries, and firm-specific skills, which are valuable only within an organization. Since then, a vast literature on the role and influence of managerial skills has demonstrated that the increased importance of general skills relative to firm-specific skills results in higher pay for generalist CEOs - that is, CEOs with more general managerial skills (Murphy and Zabojnik, 2007; Custódio et al., 2013) — and that firms run by generalist CEOs exhibit higher risk (May, 1995), increased corporate innovation (Custódio et al., 2017), higher costs of equity (Mishra, 2014), 
and improved investment efficiency (Xuan, 2009). Our focus is whether firms with generalist CEOs undertake more or less CSR activity. ${ }^{1}$

Generalist CEOs can move across firms and industries more easily, given their more diverse professional skills and experience compared to CEOs with focused business experience. Thus, the broader set of outside options available to generalist CEOs makes their long-term wealth less contingent on the future prosperity of the firm (Mishra, 2014). In turn, the reduced contingency could provide generalist CEOs with incentives to engage in projects with nearterm payoffs and dislike those with long-term payoffs. We therefore expect that generalist CEOs are less likely to engage in CSR activity because CSR is highly intangible, with valuation difficulties (Deng et al., 1999; Hong et al., 2000; Edmans, 2011). Additionally, CSR typically requires the slow, time-consuming process of improving firm-stakeholder relationships and the financial returns are thus not immediate, if any (Zadek, 2004; Deckop et al., 2006; Kang, 2016).

We use the variable General Ability Index, or GAI, developed by Custódio et al. (2013), to measure general managerial skills. The index incorporates five aspects of a CEO's lifetime career experience, including the past number of (i) positions, (ii) firms, and (iii) industries in which the CEO worked; (iv) whether the CEO has held a CEO position at a different company; and (v) whether the CEO has worked for a conglomerate firm. Following previous literature

\footnotetext{
${ }^{1}$ Examples of general human capital are economics, management science, accounting, and finance expertise, which are applicable across organizations or industries. Examples of firm-specific human capital include knowledge about or connections with product markets, suppliers, and clients, which are specific to a given organization or industry. A similar concept is labor mobility of various occupations. Certainly, some occupations are more mobile than others. The labor mobility of an occupation depends on its skill requirements. The more general (firm-specific) the required skills are, the more (less) mobile the occupation is. For example, travel agents are relatively less mobile than accounting clerks because the former occupation requires relatively less general skills, whereas the latter requires less firm-specific skills. Custódio et al. (2013) propose an indirect measure of general managerial ability based on past work experience. The intuition behind this measure is that a CEO who worked in different organizational areas, for multiple firms, in different industries, or in a conglomerate firm, or who has served as CEO previously would have more general skills, either due to self-selection or as a result of learning, and in turn more outside options. We conjecture that generalist CEOs are likely to be short-term orientated and less concerned about the firm's long-term prosperity and CSR. One prominent case in point is Kenneth Lay, who was the founder, CEO and Chairman of Enron and was heavily involved in the Enron scandal, a major accounting scandal that unraveled in 2000. On the other hand, he served in numerous positions, firms, and industries and has a GAI of 4.303 as of 2000, compared to the sample mean of 0.043 , indicating high general managerial ability. Another example is Dennis Kozlowski (a GAI of 3.586 as of 2002), a former CEO of Tyco International Ltd. In 2002, he was charged with, and later convicted of, $\$ 600$ million fraud scheme.
} 
(Deng et al., 2013; Lins et al., 2017), we use the modified CSR score to measure firm CSR performance using data obtained from the database of Kinder, Lydenberg, and Domini (KLD). Consistent with our prediction, we find a negative and statistically significant relation between the general ability index and the CSR score. Specifically, our baseline regression results suggest that a one standard deviation increase in the general ability index is associated with a 0.034 decrease in the CSR score, or a $16.17 \%$ drop from the mean. This finding is robust to alternative measures of CSR, different empirical specifications, and alternative clustering.

While the baseline results are robust and consistent with our hypothesis, the estimated negative relation between general managerial skills and CSR could be spurious. For instance, there could always be some unobserved factors influencing both the presence of a generalist CEO and the firm's CSR strategy. It could also be the case that firms with more socially responsible investments are less likely to appoint generalist CEOs if CSR performance is fueled largely by firm-specific skills that generalists lack. We adopt two identification strategies to address endogeneity concerns and help establish causality. Our first strategy is to use propensity score matching to compare firms with generalist CEOs to otherwise indistinguishable firms with specialist CEOs. Generalist CEOs are CEOs with a general ability index above the yearly median and those with an index below the yearly median are specialists. The results suggest a significant difference in the level of CSR between the two groups. Firms with generalist CEOs undertake significantly less CSR activity than the matched control group with specialist CEOs, confirming the baseline results.

Our second identification strategy is to employ the instrumental variables (IV) approach. As a source of exogenous variation in general managerial skills, we use the variable Recession depth to exploit differences in labor market conditions at the beginning of a CEO's career. This variable is defined as the depth of the recession if there was a recession in the year a CEO's career started and zero otherwise, where a recession's depth is the number of months it lasted. 
We use Recession depth instead of just a dummy for whether there was a recession because the severity of a recession could capture additional heterogeneity in the CEO's career progression and a resulting skill set that is not explained by the recession year dummy. Moreover, we follow the approach of Schoar and Zuo (2017) and look at the expected starting year by using a person's birth year plus 24 (i.e., the modal age for starting one's first position in their sample). A potential concern with using the actual starting year is that individuals could delay entering the job market during a recession, resulting in endogenously determined labor market entry. Instead, we focus on the expected starting year, which corresponds to when CEOs would likely have started their careers had endogenous choices in timing their labor market entry not taken place.

This identification strategy exploits the fact that economic conditions when CEOs start their first job have a significant impact on their subsequent career development and, in turn, managerial skills gathered through their lifetime work experience. Specifically, Schoar and Zuo (2017) document that CEOs who started their careers during recessions have less mobility across industries and firms and hold fewer positions before first becoming CEO. In other words, such CEOs could have fewer opportunities to develop general managerial skills compared to those who started in non-recession years.

On the other hand, the economic conditions in a CEO's expected year of entry into the labor market is plausibly exogenous to the CEO's career choices, since a person's birth date is largely exogenous to that person's life. Obviously, CEOs who started their careers in a recession year could differ systematically from CEOs who started in a normal year, but we assume that recession and non-recession CEOs do not differ in their attitudes toward CSR activity for reasons other than differential career histories, a key component of the General Ability Index. Consistent with this view, Schoar and Zuo (2017) find suggestive evidence that there are no significant differences in observable backgrounds between recession and non- 
recession CEOs (e.g., their educational attainment and the quality of the schools they attended), which we confirm using our data. Nevertheless, we acknowledge that, in the absence of a natural experiment, it is never possible to completely rule out remaining unobservable characteristics that can influence our results. Overall, we find, as expected, that Recession depth is negatively and significantly correlated with the general ability index. In addition, secondstage regression results confirm the negative impact of general managerial skills on CSR.

In supplementary tests, we exploit the difference in the value of outside options between generalist and specialist CEOs. To capture the variation in the value of outside options, we use a measure of the tightness of the local labor market following Custódio et al. (2017) and Kedia and Rajgopal (2009). The tighter the labor market, the stronger the demand for workers and managerial talent and the higher the likelihood of CEOs receiving outside job offers from other firms in the region. Moreover, generalist CEOs should benefit more than specialist CEOs in tight labor markets because they have more transferable skills and are more likely to capitalize on a favorable job market. Consistent with this view, we find suggestive evidence that the negative relation between the general ability index and CSR is more prominent in tight labor markets. Finally, we find that the negative effect of general managerial skills on CSR is greater for firms whose shareholders are more short term oriented, consistent with the notion that generalist CEOs are more concerned about labor market evaluation, which is driven largely by current performance.

Our study complements previous literature on the role of the CEO in fostering CSR activity. Existing findings demonstrate that CSR is related to various CEO characteristics, such as CEO confidence (Tang et al., 2015; McCarthy et al., 2017), CEO age (Oh et al., 2016), monetary and nonmonetary incentives (Fabrizi et al., 2014), and the CEO's parenting experience (Cronqvist and Yu, 2017). We show that a firm's CSR activity can be significantly altered by its CEO's general human capital. Further, our findings contribute to a better 
understanding of how the composition of a CEO's managerial skills influences the CEO's incentives and decision making. Custódio et al. (2017) argue that the broader set of outside options available to generalist CEOs acts as a labor market mechanism that increases their tolerance for failure, which in turn promotes innovation. Our findings suggest that this labor market mechanism could also make a CEO's long-term wealth less contingent on the future prosperity of the firm, rendering CSR activity less appealing from a generalist CEO's perspective.

The remainder of the paper is organized as follows. Section 2 reviews the related literature. Section 3 describes the data, sample selection, and summary statistics. Section 4 discusses the main results along with endogeneity issues. Section 5 presents further analysis results. Section 6 tests the robustness of our findings and Section 7 concludes the paper.

\section{Related literature}

\subsection{Managerial incentive and labor market evaluation}

A growing body of research provides evidence that the labor market uses firm performance as an indicator of managerial ability and that there is a positive relation between firm performance and labor market rewards for managers. For example, Gilson (1990) and Kaplan and Reishus (1990) find that managers from superior-performing firms are more likely to receive additional directorship positions, suggesting that superior performance increases the demand for a manager's services. Fee and Hadlock (2003) examine executives who switch employers and find that above-average stock price performance increases the likelihood of an executive moving to a CEO position at another firm. This finding is consistent with the view that superior firm performance improves an executive's external labor market opportunities. Another insight from this strand of literature concerns the issue of timing: firm performance during the last years before entering the external labor market more critically determines an executive's value 
in the labor market than that of more distant years. Using samples of retired CEOs, Brickley et al. (1999) and Evans et al. (2010) show that firm performance in the last two years of a CEO's tenure is much stronger than firm performance in the last three to four years at predicting a CEO's directorships after retirement.

Given the decisive impact of current firm performance on their prospects in the labor market, managers who are more concerned about labor market evaluation could have stronger incentives to commit firm resources to short-term-oriented projects and minimize commitment to long-term-oriented projects or to those that are hard to value (Holmstrom and Costa, 1986; Stein, 1989; Bebchuk and Stole, 1993; Goel and Thakor, 2008). In addition, Narayanan (1985) argues theoretically that, given the competitive nature of the labor market, managers could make decisions that yield short-term profits at the expense of the firm's long-term interests to improve perceptions about their ability early and hence earn higher wages. Relatedly, a number of studies document that managers under takeover threat could forsake good investments to boost current earnings (Stein, 1989), whereas those with long-term contracts are less likely to behave myopically and more likely to commit resources to enhance firm reputation over the long run compared to those with short-term contracts (Whetten and Mackey, 2002; Cziraki and $\mathrm{Xu}, 2017)$.

\subsection{Generalist CEOs and CSR}

Custódio et al. (2013) define generalist CEOs as those CEOs who are richly endowed with general managerial skills acquired through their lifetime work experience, as opposed to specialist CEOs, who are characterized by firm- or industry-specific skills. Unlike specific managerial skills that are highly valuable primarily within a particular firm or industry, general managerial skills are readily transferable across entities and sectors. Thus, generalist CEOs with a broader set of outside options are more likely to engage in job hopping to capitalize on 
a favorable job market (Giannetti, 2011). Consistent with this logic, prior studies show that generalist CEOs are frequently approached by executive search consultants and have an easier time finding and obtaining offers from other comparable firms (Dasgupta and Ding, 2010; Giannetti, 2011; Mishra, 2014). Therefore, the long-term wealth of a generalist CEO is less contingent on the firm's future prosperity than that of a specialist CEO. The reduced contingency could have a significant impact on corporate decisions, since CEOs with general managerial skills have incentives to engage in projects with near-term payoffs to inflate current performance and dislike projects with long-term payoffs even though these could enhance the firm's longevity or sustainability. In contrast, CEOs with focused professional experience and skill sets are more likely to choose internal operations that involve interactions with clients, suppliers, and employees as their strategic priority (Murphy and Zabojnik, 2007; Lazear, 2009; Custódio et al., 2013).

Given the interaction between labor market evaluation and executive skill sets and resulting managerial incentive problems, we expect generalist CEOs to be less likely to invest in CSR due to the following features of CSR activity. First, the empirical evidence on the link between CSR and firm performance is largely ambiguous, rendering the performance implications of CSR unclear (for a review, see Ferrell et al., 2016). A strand of research argues that CSR activity is a time-consuming process that improves firm-stakeholder relationships and thereby contributes to firm performance in the long run (Cornell and Shapiro, 1987; Donaldson and Preston, 1995; Freeman et al., 2004; Brammer and Millington, 2008; Godfrey et al., 2009; Kacperczyk, 2009; Deng et al., 2013). However, the financial benefit of CSR is clouded by the view that CSR represents primarily a practice that deviates from profit maximization, which could result in a misallocation of resources and impairment of shareholder wealth (Thomas and Ely, 1996; Ogden and Watson, 1999; Zadek, 2004; Deckop et al., 2006; Kang, 2016). For instance, Kruger (2015) examines stock market reactions to CSR event announcements and 
shows that the stock market has a strong negative reaction to negative CSR events and a weak negative reaction to positive CSR events, suggesting that CSR and firm performance, especially in the short term, might not go hand in hand.

Second, the intangible and sometimes invisible nature of CSR activity means that it is difficult to measure CSR in terms of either its input or output values. One implication of this intangibility is that the stock market might not fully value a firm's CSR activity. Indeed, much of the prior literature argues that intangibles such as CSR are not fully incorporated because the market lacks information on their value (Lev and Sougiannis, 1996; Chan et al., 2001; Lev, 2004). Even if such information were available, the market might ignore it if it were not salient, given ambiguous predictions on whether CSR enhances firm performance. Another explanation of non-incorporation is that investors use traditional valuation methodologies devised for firms comprised mainly of physical assets, which cannot easily incorporate intangibles (Deng et al., 1999; Hong et al., 2000; Edmans, 2011).

Taken together, generalist CEOs have greater bargaining power in the labor market and can move across firms and industries more easily than specialist CEOs, given their diverse career experience and general human capital. Moreover, generalist CEOs might pay close attention to labor market evaluation and are more likely to engage in job hopping to capitalize on a favorable job market. Their long-term wealth thus becomes less contingent on the firm's future prosperity, which, in turn, induces them to reduce the level of firm commitment to longterm investment projects and be more concerned about short-term performance. Considering that the financial return from CSR activity is not immediate and requires the slow, timeconsuming process of reputation development and firm-stakeholder relationship improvement, CEOs with general managerial skills would be reluctant to give priority to CSR. 


\section{Data and summary statistics}

\subsection{Data}

We start with the corporate social responsibility rating data obtained from the KLD database over the period from 1996 to $2012 .^{2}$ To examine the effect of general managerial skills on CSR, we then merge the corporate social responsibility rating data with the general managerial ability index data provided by Custódio et al. (2013). ${ }^{3}$ The latter data cover the period only until 2007. We therefore supplement this information with our hand-collected data to include the period from 2008 to 2012. Specifically, for our sample between 1996 and 2007, we use the original general ability index data from Custódio et al. (2013). For the extended period of 2008 to 2012, we construct the general ability index ourselves following the methodology in Custódio et al. $(2013))^{4}$

Moreover, firm-level financial data are obtained from the CRSP-Compustat Merged Database, corporate governance and director characteristics data are from RiskMetrics, and institutional investor data are from CDA/Spectrum 13F filings. We consider also a number of CEO characteristics including educational attainment and past experience, which have been collected from BoardEx, Bloomberg, and LinkedIn, using procedures and definitions following the existing literature (Bhagat et al., 2010; Cronqvist et al., 2012; and Benmelech and Frydman, 2015). Our final sample consists of 10,750 firm-year observations, representing 1,769 unique firms and 2,744 unique CEOs between 1996 and 2012.

\footnotetext{
${ }^{2}$ We start our sample in 1996 due to the availability of director characteristics information in RiskMetrics and we end the sample in 2012 because we do not have sufficient information on the seven components (i.e., community, corporate governance, diversity, employee relations, environment, human rights, and product quality) needed for calculating the overall CSR score after 2012 .

${ }^{3}$ We thank Pedro Matos for kindly providing the general ability index data.

${ }^{4}$ This extended sample consists of the index values for CEOs already exist in the 1996-2007 sample plus those of new CEOs who became CEO for the first time between 2008 and 2012.
} 


\subsection{Variable construction}

KLD divides a firm's CSR-related information into seven categories, including community, corporate governance, diversity, employee relations, environment, human rights, and product quality. Each category contains several dimensions with positive (i.e., strength) and negative (i.e., concern) indicators. Each strength or concern is assigned the value of one if it meets the criteria. Similar to Deng et al. (2013) and Lins et al. (2017), we construct the modified CSR measure in three steps. First, we divide the strength and concern scores for each category by the number of strength and concern indicators in that category, respectively, to obtain modified scores. Second, we derive the net score for each category by subtracting the modified concern score from the modified strength score. Finally, we aggregate individual scores to form an overall CSR score. $^{5}$

Our measure of general managerial skills is the general ability index developed by Custódio et al. (2013). The value of the index for CEO $i$ in year $t$ is calculated based on the following model:

$$
G A I_{i, t}=0.268 X 1_{i, t}+0.312 X 2_{i, t}+0.309 X 3_{i, t}+0.218 X 4_{i, t}+0.153 X 5_{i, t}
$$

where $X 1$ is the number of positions the CEO held during his or her career, $X 2$ is the number of firms where a CEO worked, $X 3$ is the number of industries at the four-digit SIC level in which a CEO worked, $X 4$ is a dummy variable that equals one if the $\mathrm{CEO}$ held a CEO position at another firm, and $X 5$ is a dummy variable that equals one if the CEO worked for a multidivision firm. The index is the first factor of a principal components analysis of the five proxies. A higher value of the index indicates greater general managerial ability. As in Custódio et al. $(2013,2017)$, the index is standardized to have a zero mean and a unit standard deviation.

\footnotetext{
${ }^{5}$ For example, the KLD CSR strength and concern scores of the seven categories for Starbucks in 2003 are 2, 0, 1, 2, 0, 0, 0 and $0,1,0,1,0,0,0$, respectively. The corresponding numbers of strength and concern indicators are $6,4,8,6,5,3,4$ and 4 , $3,3,5,7,4,4$. Thus, the modified strength and concern scores can be calculated as $0.7916(=2 / 6+0 / 4+1 / 8+2 / 6+0 / 5+0 / 3$ $+0 / 4)$ and $0.5333(=0 / 4+1 / 3+0 / 3+1 / 5+0 / 7+0 / 4+0 / 4)$, respectively. Finally, the overall CSR score for Starbucks in 2003 is $0.2583(=0.7916-0.5333)$.
} 
Motivated by the previous CSR literature (e.g., Branco and Rodrigues, 2006; Godfrey et al., 2009; Barnea and Rubin, 2010; Manner, 2010; Borghesi et al., 2014; Rao and Tilt, 2016), we include a wide range of controls for CEO, firm, and governance characteristics. First, we include controls for $\mathrm{CEO}$ characteristics, including $C E O$ gender, $C E O$ duality, $C E O M B A$, CEO Ivy league, ${ }^{6}$ CEO military, CEO age, CEO tenure, and CEO fast track to capture other CEO characteristics that may influence the level of CSR. In addition, we include Size, ROA, Stock return, Leverage, Tobin's Q, Asset tangibility, and Firm age to account for firm characteristics that could potentially affect the level of CSR. Finally, we include Board independence, Board busyness, and Institutional holdings to capture the potential effect of corporate governance on CSR. Detailed variable definitions are provided in the Appendix. Throughout our analysis, the explanatory variables are lagged one year relative to the dependent variable to alleviate potential endogeneity problems. All accounting variables are winsorized at the $1^{\text {st }}$ and $99^{\text {th }}$ percentiles.

\subsection{Summary statistics}

Table 1 reports the descriptive statistics for the variables used in our baseline regression models. The average CEO is 55 years old and has a tenure of eight years and a general ability index score of 0.043 . Further, $1.9 \%$ of the CEOs in the sample are female, $66.4 \%$ of them also chair the board, 33.2\% have an MBA, $18.8 \%$ attended an Ivy League university, and $6.9 \%$ have military experience. The average age when our sample CEOs became a CEO for the first time is 46. An average firm in our sample has a CSR rating score of -0.213 , a sales revenue of $\$ 6.388$ billion, a return on assets of $13.7 \%$, a stock return of $13.5 \%$, a leverage of 0.213 , a

\footnotetext{
${ }^{6}$ We collect as much education information as thoroughly and systematically as possible. We start with the education information disclosed in BoardEx. The disclosures about education in BoardEx differ across CEOs in the sample. Some disclosures include specific information about school, type of degree, major and year. Others provide just the name of the school. We then supplement this information with data obtained from Bloomberg Executive Profile \& Biography and LinkedIn. Finally, we delete 36 CEOs with no education information in any of the above sources.
} 
Tobin's Q of 1.946, a fraction of tangible assets of $26.9 \%$, a firm age of approximately 27 years, a fraction of independent directors of $71.9 \%$, a fraction of busy directors of $27.1 \%$, and a fraction of institutional holdings of $76.2 \%$. All these descriptive statistics are comparable to those reported by Deng et al. (2013), Custódio et al. (2013), Borghesi et al. (2014), Mishra (2014), Tang et al. (2015), and Hubbard et al. (2017).

\section{[Insert Table 1 about here]}

Panel A of Table 2 compares the characteristics of firms run by generalist CEOs and those of firms run by specialist CEOs at the firm-year level. We classify observations with a general ability index above the yearly median as generalists and those with an index below the yearly median as specialists. On average, firms with generalist CEOs have lower CSR rating scores than those with specialist CEOs. Further, firms with generalist CEOs are bigger and older, have higher leverage, hold more tangible assets, have a more independent and busier board, and have more institutional holdings. Panel B compares the personal characteristics of generalist CEOs and those of specialist CEOs at the CEO level. For each of the 2744 unique CEOs, we calculate an average general ability index across all years in the sample. ${ }^{7}$ We then classify them into the generalist and specialist groups based on the median of the average general ability index. Similar to Custódio et al. (2013), we find that generalist CEOs tend to be older, to have a shorter tenure, to be more likely to hold a dual CEO-chair title, have an MBA, have an academic degree from an Ivy League university, or have a history of military service; and were approximately two years older when they became a CEO for the first time than the average specialist CEO was.

\section{[Insert Table 2 about here]}

\footnotetext{
${ }^{7}$ Other personal characteristic variables are also aggregated to the CEO level (by taking averages over years) before conducting the univariate analysis.
} 


\section{Main results}

\subsection{General managerial ability and CSR}

Panel A of Table 3 presents our baseline results on the relation between general managerial skills and CSR activity. In each regression, we include industry and year fixed effects to account for macroeconomic shocks in a specific industry in a given year. Column (1) shows that the coefficient of General Ability Index is negative and statistically significant at $1 \%$ level, suggesting that general managerial skills are negatively related to CSR. In terms of economic significance, the coefficient of General Ability Index in column (1) indicates that a one standard deviation increase in General Ability Index is associated with a 0.034 decrease in the CSR score, or a $16.17 \%$ drop from the mean. Alternatively, we define the general ability variable as a dummy based on the sample median of General Ability Index on a yearly basis and use it to explain CSR. In column (2), we find that the coefficient of General Ability Index_dummy remains negative and significant at the $1 \%$ level.

In Panel B, we estimate several other specifications for robustness. First, in columns (1) and (2), we use firm fixed effects regressions to mitigate the concern that the results are driven by unobserved factors at the firm level. The coefficient on the general ability variable remains negative and statistically significant at the $5 \%$ level in both specifications, suggesting that firmspecific time-invariant unobservables cannot explain our findings. Second, one possibility is that certain personality traits might influence both the CEOs' career trajectory and their attitudes towards CSR. For example, sensation seeking CEOs, with a desire to pursue novel experiences by working in multiple firms and industries, may find CSR projects less interesting and creative. Alternatively, selfish CEOs focusing on enriching their resume might care less about the firm's long term prosperity and in turn CSR. To address these potential confounding effects, we incorporate CEO fixed effects to account for any differences in personality traits between CEOs that are invariant throughout the sample period. We find in columns (3) and (4) 
that the negative effect of general managerial ability on CSR is robust to using CEO fixed effects, suggesting CEO personality traits alone cannot explain our findings. Third, we use Fama-MacBeth regressions with Newey-West standard errors to examine the cross-sectional relationship between general managerial ability and CSR in columns (5) and (6). The results show that the coefficient on the general ability variable remains negative and statistically significant at the 5\% level in both regressions, confirming the negative effect of general managerial ability on CSR.

\section{[Insert Table 3 Here]}

\subsection{Endogeneity}

Our results so far indicate a negative relation between the CEO's general managerial ability and the level of CSR. However, this finding could be biased due to endogenous matching between the firm and the CEO. For instance, firms with more socially responsible investments could place greater emphasis on maintaining good stakeholder relationships and are thus less likely to appoint managers with little firm-specific knowledge in dealing with stakeholders (Miller, 1991; Datta et al., 2002). We attempt to mitigate endogeneity concerns by adopting two identification strategies. Our first strategy is to use propensity score matching, whereby firm-years with generalist CEOs are matched with those with specialist CEOs that exhibit no significant differences in other observable characteristics. Our second strategy is to employ an instrumental variables approach to alleviate concerns relating to reverse causation and omitted factors.

\subsubsection{Propensity score matching estimates}

Table 4 compares the CSR of firms with generalist CEOs with that of firms with specialist CEOs that have been matched to the former using propensity score matching. We first estimate 
a logit regression of whether a firm has a generalist CEO. The propensity score is then the probability estimated from the logit regression. We include the same set of controls as in the baseline regression shown in Table 3. The results presented in column (1) of Panel A of Table 4 suggest that firms with generalist CEOs are larger.

We then apply the nearest-neighbor method to ensure that firms with generalist CEOs (treatment group) are sufficiently similar to their matched firms with specialist CEOs (control group). Specifically, each firm with a generalist CEO is matched to a firm with a specialist CEO with the closest propensity score. If a firm in the control group is matched to more than one firm in the treatment group, only the pair with the smallest difference in propensity scores between the two firms is retained. ${ }^{8}$ We further require that the maximum difference in propensity scores between the treatment and its matched control firms does not exceed $0.1 \%$ in absolute value. ${ }^{9}$

We conduct two diagnostic tests to verify that the observations in the treatment and control groups are sufficiently indistinguishable in terms of observable characteristics. The first test involves re-estimating the logit model using the matched sample. The results are reported in column (2) in Panel A of Table 4. None of the coefficient estimates is statistically significant, indicating no distinguishable trends between the treatment and control groups. In addition, most of the coefficients in column (2) are smaller in magnitude than those in column (1), implying that the results are not merely an artifact of a decline in the number of degrees of freedom in the restricted sample. Further, the pseudo-R-squared value decreases from 0.118 in the pre-match sample to only 0.002 in the post-match sample.

\footnotetext{
${ }^{8}$ As a robustness check, we allow for control firms to be matched to multiple treatment firms. The results do not change qualitatively.

${ }^{9}$ Our results remain consistent when we increase the maximum permissible difference in propensity scores to $0.5 \%$ and $1.0 \%$ in absolute value.
} 
The second test is to examine the difference in means for each observable characteristic between the treatment and matched control groups. The results are reported in Panel B of Table 4. The observation that none of the differences is statistically significant confirms the findings in column (2) of Panel A. Overall, the diagnostic test results appear to suggest that propensity score matching removes observable differences other than the difference in CEO type between the treatment and control groups. Thus, it increases the likelihood that any difference in CSR between the two groups is due to the presence of generalist CEOs. Finally, Panel C presents the propensity score matching estimates. The results suggest that firms with generalist CEOs tend to have much lower CSR scores compared to otherwise indistinguishable firms with specialist CEOs.

\section{[Insert Table 4 Here]}

\subsubsection{Instrumental variables approach}

We also employ an instrumental variables approach to extract the exogenous component of General Ability Index and use it to explain CSR. Our instrumental variable Recession depth exploits the variation in labor market conditions at the beginning of a CEO's career. It is defined as the depth of the recession if there is a recession in the year when a CEO's career starts and zero otherwise, where a recession's depth is the number of months that it lasts. Recession periods are defined based on the business cycle dating database of the National Bureau of Economic Research (NBER). Specifically, to be classified as a recession year, the (calendar) year must either include the trough of a business cycle or fully fall into a recession period (excluding the peak of a business cycle). All remaining years are non-recession years. We use Recession depth instead of just a dummy for whether there is a recession because the severity of a recession could capture additional heterogeneity in the CEO's career progression and a resulting skill set that is not explained by the recession year dummy. 
To explore the economic conditions at the time of the CEO's job market entry, we follow the approach of Schoar and Zuo (2017) and proxy for the exogenous starting year by using a person's birth year plus 24 (i.e., the age at which managers are most likely to start their first full-time job). This approach helps purge the estimation bias resulting from the possibility that the actual starting year is endogenously determined. If the most well-informed, intelligent individuals postpone their entrance into the labor market during a recession while the average employee does not, then this phenomenon would represent a selection issue. Instead, we focus on the expected starting year, which corresponds to when CEOs would likely have started their careers if endogenous choices in timing their labor market entry had not taken place.

Schoar and Zuo (2017) show that the economic conditions when CEOs first enter the labor market have significant effects on their career paths and, in turn, the managerial skills gathered through their work experience. Specifically, CEOs who started their careers during recessions have less mobility across industries and firms and hold fewer positions before first becoming CEO. Thus, such CEOs could have fewer opportunities to develop general managerial skills compared to those who started in other years, suggesting a negative relation between Recession depth and the acquisition of general managerial skills. On the other hand, the economic conditions in a CEO's expected year of entry into the labor market lie outside the CEO's control, since a person's birth date is largely exogenous to his or her life. Thus, it is plausible that starting one's career during a recession, as an exogenous formative event, does not directly affect the CEO's decisions with respect to the current firm's CSR activity, except through the composition of managerial skills (developed over the CEO's past career experience) or the variables we control for.

Column (1) of Table 5 presents the first-stage regression results where the dependent variable is General Ability Index. Consistent with our prediction, the coefficient of Recession depth is negative and statistically significant at the $1 \%$ level, indicating that CEOs who started 
their careers during (severe) recessions have less general managerial skills. The reported Fstatistic is 18.48 , which is larger than the conventional threshold for weak instruments. Column (2) shows the second-stage regression results, where the dependent variable is the CSR rating. The main variable of interest is the predicted value of General Ability Index. Its coefficient remains negative and significant at the $5 \%$ level, which is reassuring. CEOs with more general managerial skills invest less in CSR, after endogeneity is mitigated, confirming our baseline results.

\section{[Insert Table 5 Here]}

A key identifying assumption for the instrumental variables approach is that our instrument, Recession depth, is uncorrelated with CSR except through the control variables included in the regression (i.e., the exclusion condition). While it is never possible to completely rule out violations of this condition, we can explore whether the data are consistent with particular violations. One potential concern here is that CEOs who have prior recession experience (following their CEO appointment) may behave differently than other CEOs (Blank and Hadley, 2018). In particular, living through hardship in the past could make a person more compassionate, care more about others, and thus more willing to engage in CSR projects, suggesting a link between recession experience and CSR orientation. To address this possibility, we construct a more direct measure of managerial prior recession experience, Recession CEO, an indicator variable taking a value of one if the CEO has previously experienced a recession during his or her CEO tenure and, zero otherwise. We then use this variable to explain the firm's CSR scores in subsequent one to three years, respectively, including the same set of controls as the baseline model. The results (unreported) show that the coefficient on Recession $C E O$ is statistically insignificant across all specifications. We therefore do not find evidence that recession experienced CEOs invest more in CSR. 


\section{Further analysis}

\subsection{Effect of outside options}

Our results so far are consistent with the notion that generalist CEOs undertake less CSR activity. In this section, we examine whether the negative relation between the general ability index and the level of CSR is affected by the value of the CEO's outside options. Following Custódio et al. (2017) and Kedia and Rajgopal (2009), we use the tightness of the local labor market (as a measure of labor market conditions) to capture the variation in the value of outside options. The tighter the labor market, the stronger the demand for workers, as well as managerial talent, and the higher the likelihood that CEOs receive outside job offers from other firms in the region. ${ }^{10}$ Given that generalist CEOs have more transferable skills and are more likely to capitalize on a favorable job market, they should benefit more than specialist CEOs in tight labor markets. We therefore expect the relation between the general ability index and CSR activity to be more prominent in tight labor markets.

\section{[Insert Table 6 Here]}

In Table 6, we estimate the effect of General Ability Index on CSR separately for subsamples in labor markets with high and low levels of tightness. We split the sample into high- and low-tightness groups based on state-level unemployment rates. ${ }^{11} \mathrm{~A}$ state is in the high-tightness (low-tightness) group if it has an unemployment rate that is below (above) the sample median across all states in a given year. The regressions include the same controls as in previous tables. We find suggestive evidence that the effect of general managerial skills on

\footnotetext{
${ }^{10}$ The presumption in this analysis is that the managerial labor market is geographically segmented. Indeed, on the demand side, firms may hire locally to reduce search costs, to have better access to soft information about local candidates, or to enjoy private benefits from hiring local candidates. On the supply side, executives may want to work for local firms because they prefer living and working close to home, or because they possess valuable geographic-specific skills (Knyazeva et al., 2013; Yonker, 2017). Empirically, Fahlenbrach et al. (2010) and Bouwman (2011) document that CEOs are more likely to hold outside directorships at nearby firms. Further, Yonker (2017) provides evidence that the local hiring bias also exists in CEO appointments. He finds that firms are over five times more likely to hire a local CEO than would be expected if geography were irrelevant to the hiring process.

${ }^{11}$ The unemployment data are from the Bureau of Labor Statistics.
} 
CSR is greater in tight labor markets, where better outside options make generalist CEOs more reluctant to invest in CSR.

\subsection{Effect of the investor horizon}

If generalist CEOs are more concerned about labor market evaluation and if recent performance more critically determines their value in the labor market than performance in the distant past, we would expect the negative relation between General Ability Index and CSR to be stronger when the firm's shareholders are more short term oriented. To test this conjecture, we use Investor turnover to capture the length of the investment horizon of shareholders, following the approach of Gaspar et al. (2005). This measure exploits the fact that short-term investors buy and sell their investments more frequently and hold their portfolios unchanged for shorter periods than long-term investors. Specifically, the value of Investor turnover for a firm is the average turnover of its investors' entire portfolios, with higher values indicating shorter horizons. ${ }^{12}$

\section{[Insert Table 7 Here]}

Table 7 shows the split-sample analysis results based on the estimated investor turnover. A firm is in the high-turnover (low-turnover) group if its estimated average turnover is above (below) the sample median of Investor turnover. Estimating the effect of General Ability Index separately for the subsamples of high- and low-turnover firms, we find that the effect of general

\footnotetext{
${ }^{12}$ Using investor-level portfolio information obtained from CDA/Spectrum, we first calculate the so-called churn rate of investor $i$ with a set of companies $Q$ in his portfolio in quarter $t$ :

$$
C R_{i, t}=\frac{\sum_{j \in Q}\left|N_{j, i, t} P_{j, t}-N_{j, i, t-1} P_{j, t-1}-N_{j, i, t-1} \Delta \mathrm{P}_{j, t}\right|}{\sum_{j \in Q} \frac{N_{j, i, t} P_{j, t}+N_{j, i, t-1} P_{j, t-1}}{2}}
$$

where $P_{j, t}$ and $N_{j, i, t}$ are the price and number of shares, respectively, of firm $j$ held by institutional investor $i$ in quarter $t$. We then use the estimated churn rates to construct the investor horizon measure. Specifically, the Investor turnover value of firm $k$ is the weighted average of the total portfolio churn rates of its investors over four quarters:

$$
\text { Investor turnover of firm } k=\sum_{i \in S} w_{k, i, t}\left(\frac{1}{4} \sum_{r=1}^{4} C R_{i, t-r+1}\right)
$$

where $S$ denotes the set of institutional investors in firm $k$ and $w_{k, i, t}$ is the weight of investor $i$ in the total percentage held by institutional investors in quarter $t$.
} 
managerial skills on CSR is concentrated among firms held by short-term investors, consistent with our prediction.

\section{Robustness tests}

In this section, we perform several robustness checks of our main findings. First, in Panel A of Table 8, we examine the effect on the change in CSR rating when a firm switches CEO type from generalist to specialist or vice versa. CEOs are classified as generalists (specialists) if their General Ability Index is above (below) the sample median in each year. This analysis is based on 683 CEO turnovers during our sample period, where CEO turnover is defined as any change in the person identified as the CEO between year $t-1$ and year $t$. The regression includes the same set of control variables, but all in (contemporaneous) changes, and industry and year effects as in our baseline specification. We use two variables to measure the switch of CEO type. Specialist to generalist (Generalist to specialist) is a dummy that equals one if a specialist (generalist) CEO at year $t-1$ is replaced by a generalist (specialist) CEO at year $t$, and zero otherwise. The holdout group in this specification consists of cases with no CEO type change. The results show that the coefficient on Specialist to generalist is negative and statistically significant and that of Generalist to specialist is positive and significant. Moreover, these two coefficients are statistically different from each other as shown by the F-statistic at the bottom of the panel. These findings are consistent with our main hypothesis: an increase (decrease) in CSR rating occurs when a generalist (specialist) is replaced by a specialist (generalist), consistent with general ability reducing managers' incentives to engage in CSR activity.

Second, we use alternative measurements of CSR. The variable CSR Net is defined simply as the sum of all strength items minus the sum of all concern items, following Borghesi et al. (2014), Kang (2016), and McCarthy et al. (2017). Moreover, Tang et al. (2015) and Choi 
and Wang (2009) indicate that some CSR categories in the KLD database are less relevant to stakeholders. We therefore adjust our CSR measures by focusing on the five main categories, including community, diversity, employee relations, environment, and product quality, for both the CSR variable used in our baseline specification and CSR Net. The resulting measures are denoted CSR_Five and CSR Net_Five, respectively. Panel B of Table 8 presents the regression results using the above alternative CSR measures. For brevity, for each regression, we report only the coefficient of the main variable of interest, namely, General Ability Index or General Ability Index_dummy, while the same set of controls and industry and year fixed effects as in our baseline specification are included. We find that the coefficient of the general ability variable is negative and statistically significant at least at the $5 \%$ level across all specifications, suggesting that our results are robust to alternative ways of measuring CSR.

\section{[Insert Table 8 Here]}

Third, McWilliams and Siegel (2001) argue that investment in research and development (R\&D) could result in both CSR-related process and product innovations, which are each valued by some consumers. To account for any potential impact of a firm's R\&D activity on its CSR performance, we include R\&D expenditure (scaled by total assets) as an additional control. The results reported in Panel $\mathrm{C}$ of Table 8 are materially unaffected by this inclusion.

Fourth, an alternative explanation of our baseline results is that firms managed by generalist CEOs have higher cost of capital (Mishra, 2014), making it more costly for them to invest in CSR. To ensure that this explanation does not drive our findings, in Panel C of Table 8, we include Cost of capital, constructed following Dhaliwal et al. (2011), as an additional control. ${ }^{13}$ Our results remain qualitatively similar.

\footnotetext{
${ }^{13}$ Following Dhaliwal et al. (2011), cost of equity capital is calculated as the mean value of three cost of equity capital measures developed by Gebhardt et al. (2001), Claus and Thomas (2001), and Easton (2004), respectively.
} 
Fifth, previous literature shows that executive compensation arrangements play an important role in determining CSR activity (McGuire et al., 2003; Deckop et al., 2006; Fabrizi et al., 2014) and that generalist CEOs earn higher pay than their specialist counterparts, reflecting the relative importance of general managerial skills in the labor market (Custódio et al., 2013). To mitigate the concern that executive compensation is an omitted factor in our model, we include the natural logarithm of CEO total compensation to account for the level of executive compensation. In an alternative specification, we include the natural logarithm of one plus $C E O$ delta (i.e., the dollar change in wealth associated with a $1 \%$ change in the firm's stock price) and the natural logarithm of one plus CEO vega (i.e., the dollar change in wealth associated with a 0.01 change in the standard deviation of the firm's returns) to account for managerial performance and risk-taking incentives, respectively. ${ }^{14}$ Panel $\mathrm{C}$ shows that controlling for these executive compensation variables does not have a large impact on the effect of general managerial skills.

Sixth, McCarthy et al. (2017) find a negative relation between CSR and CEO confidence. Following Campbell et al. (2011) and Hirshleifer et al. (2012), we use the average moneyness of a CEO's stock options to capture the CEO's confidence beliefs. Specifically, CEO confidence is a measure of the extent to which stock price exceeds the exercise price, with higher values indicating greater confidence. ${ }^{15}$ Controlling for $C E O$ confidence, we find in Panel $\mathrm{C}$ of Table 8 that the coefficients of the two general managerial ability variables remain negative and statistically significant.

\footnotetext{
${ }^{14}$ Data on CEO total compensation are sourced from Execucomp and data on CEO delta and CEO vega can be downloaded directly from https://sites.temple.edu/lnaveen/data/.

${ }^{15}$ We estimate the average CEO stock option moneyness for each year as follows. First, we calculate the average realizable value per option by dividing the total realizable value of exercisable options by the number of exercisable options. We then subtract the average realizable value from the fiscal year-end stock price to obtain the average exercise price of the options. Finally, the estimated moneyness of the options is calculated as the stock price divided by the estimated average exercise price minus one.
} 
Finally, we also test whether the results are robust to the use of alternative clustering and definitions of industry dummies. The results are shown in Panel D of Table 8. We confirm that our results are robust to clustering by year and industry, to using two-digit SIC industry dummies, and to using three-digit North American Industry Classification System (NAICS) industry dummies.

\section{Conclusion}

We document a significant negative relation between general managerial skills and CSR activity. The more general managerial skills acquired by the CEO, the less CSR activity undertaken by the firm. This finding is robust to alternative CSR measures, empirical specifications, methods of clustering, and definitions of industry dummies. To mitigate endogeneity concerns, we employ both propensity score matching and instrumental variables approaches and confirm that the effect of general managerial ability on CSR still holds in these tests. Finally, supplementary test results suggest that the negative relation between the general ability index and CSR is more pronounced in tight labor markets and in firms with more shortterm investors, consistent with the idea that the broader set of outside options available to generalist CEOs acts as a labor market mechanism that makes them less concerned about the long-term sustainability of the firm and, thus, CSR-related issues. 


\section{References}

Barnea, A., Rubin, A., 2010. Corporate social responsibility as a conflict between shareholders. Journal of Business Ethics 97, 71-86.

Bebchuk, L.A., Stole, L.A., 1993. Do short-term objectives lead to under- or overinvestment in long-term projects. Journal of Finance 48, 719-729.

Becker, G., 1962. Investment in human capital: A theoretical analysis. Journal of Political Economy 70, 9-49.

Bénabou, R., Tirole, J., 2010. Individual and corporate social responsibility. Economica 77, 1-19.

Benmelech, E., Frydman, C., 2015. Military CEOs. Journal of Finance Economics 117, 43-59.

Bhagat, S., Bolton, B.J., Subramanian, A., 2010. CEO education, CEO turnover, and firm performance. Working paper.

Blank, D.B., Hadley, B., 2018. When CEOs adapt: An investigation of manager experience, policy and performance following recessions. Working paper.

Borghesi, R., Houston, J.F., Naranjo, A., 2014. Corporate socially responsible investments: CEO altruism, reputation, and shareholder interests. Journal of Corporate Finance 26, 164181.

Bouwman, C., 2011. Corporate governance propagation through overlapping directors. Review of Financial Studies 24, 2358-94.

Brammer, S., Millington, A., 2008. Does it pay to be different? An analysis of the relationship between corporate social and financial performance. Strategic Management Journal 29, $1325-$ 1343.

Branco, M.C., Rodrigues, L.L., 2006. Corporate social responsibility and resource-based perspectives. Journal of Business Ethics 69, 111-132.

Brickley, J.A., Linck, J.S., Coles, J.L., 1999. What happens to CEOs after they retire? New evidence on career concerns, horizon problems, and CEO incentives. Journal of Financial Economics 52, 341-377.

Campbell, T.C., Gallmeyer, M., Johnson, S.A., Rutherford, J., Stanley, B.W., 2011. CEO optimism and forced turnover. Journal of Financial Economics 101, 695-712.

Chan, L.K.C., Lakonishok, J., Sougiannis, T., 2001. The stock market valuation of research and development expenditures. Journal of Finance 56, 2431-2456.

Choi, J., Wang, H.L., 2009. Stakeholder relations and the persistence of corporate financial performance. Strategic Management Journal 30, 895-907.

Claus, J., Thomas, J., 2001. Equity premia as low as three percent? Evidence from analysts' earnings forecasts for domestic and international stock markets. Journal of Finance 56, 16291666.

Cornell, B., Shapiro, A.C., 1987. Corporate stakeholders and corporate finance. Financial Management 16, 5-14. 
Cronqvist, H., Makhija, A.K., Yonker, S.E., 2012. Behavioral consistency in corporate finance: CEO personal and corporate leverage. Journal of Financial Economics 103, 20-40.

Cronqvist, H., Yu, F., 2017. Shaped by their daughters: Executives, female socialization, and corporate social responsibility. Journal of Financial Economics 126, 543-562.

Custódio, C., Ferreira, M.A., Matos, P., 2013. Generalists versus specialists: Lifetime work experience and chief executive officer pay. Journal of Financial Economics 108, 471-492.

Custódio, C., Ferreira, M.A., Matos, P., 2017. Do general managerial skills spur innovation? Management Science 65, 459-476.

Cziraki, P., Xu, M.Q., 2017. CEO turnover and risk taking under long-term employment contracts. Unpublished working paper, University of Toronto.

Dasgupta, S., Ding, F., 2010. Search intermediaries, internal labor markets, and CEO pay. Unpublished working paper. Hong Kong University of Science and Technology.

Datta, D.K., Guthrie, N., Rajagopalan, J.P., 2002. Different industries, different CEOs? An empirical study of career specialization. Human Resource Planning 25, 14-25.

Davidson, R.H., Dey, A., Smith, A.J., 2016. CEO materialism and corporate social responsibility. Chicago Booth Research Paper No. 16-11.

Deckop, J.R., Merriman, K.K., Gupta, S., 2006. The effects of CEO pay structure on corporate social performance. Journal of Management 32, 329-342.

Deng, X., Kang, J.K., Low, B.S., 2013. Corporate social responsibility and stakeholder value maximization: Evidence from mergers. Journal of Financial Economics 110, 87-109.

Deng, Z., Lev, B., Narin, F., 1999. Science and technology as predictors of stock performance. Financial Analysts Journal 61, 51-63.

Dhaliwal, D.S., Li, Z.O., Tsang, A., Yang, Y.G., 2011. Voluntary nonfinancial disclosure and the cost of equity capital: The initiation of corporate social responsibility reporting. The Accounting Review 86, 59-100.

Donaldson, T., Preston, L.E., 1995. The stakeholder theory of the corporation: Concepts, evidence, and implications. Academy of Management Review 20, 65-91.

Easton, P., 2004. PE ratios, PEG ratios, and estimating the implied expected rate of return on equity capital. The Accounting Review 79, 73-95.

Edmans, A., 2011. Does the stock market fully value intangibles? Employee satisfaction and equity prices. Journal of Financial Economics 101, 621-640.

Evans, J.H., Nagarajan, N.J., Schloetzer, J.D., 2010. CEO Turnover and retention light: retaining former CEOs on the board. Journal of Accounting Research 48, 1015-1047.

Fabrizi, M., Mallin, C., Michelon, G., 2014. The role of CEO's personal incentives in driving corporate social responsibility. Journal of Business Ethics 124, 311-326.

Fahlenbrach, R., Low, A, Stulz, R., 2010. Why do firms appoint CEOs as outside directors? Journal of Financial Economics 97, 12-32. 
Fee, C.E., Hadlock, C.J., 2003. Raids, rewards, and reputations in the market for managerial talent. Review of Financial Studies 16, 1315-1357.

Ferrell, A., Liang, H., Renneboog, L., 2016. Socially responsible firms. Journal of Financial Economics 122, 585-606.

Freeman, R.E., Wicks, A.C., Parmar, B., 2004. Stakeholder theory and "the corporate objective revisited". Organization Science 15, 364-369.

Gaspar, J.M., Massa, M., Matos, P., 2005. Shareholder investment horizons and the market for corporate control. Journal of Financial Economics 76, 135-165.

Gebhardt, W., Lee, C., Swaminathan, B., 2001. Toward an implied cost of capital. Journal of Accounting Research 39, 135-176.

Giannetti, M., 2011. Serial CEO incentives and the structure of managerial contracts. Journal of Financial Intermediation 20, 633-662.

Gilson, S., 1990. Bankruptcy, boards, banks, and blockholders: Evidence on changes in corporate ownership when firms default. Journal of Financial Economics 27, 355-387.

Godfrey, P.C., Merrill, C.B., Hansen, J.M., 2009. The relationship between corporate social responsibility and shareholder value: An empirical test of the risk management hypothesis. Strategic Management Journal 30, 425-445.

Goel, A.M., Thakor, A.V., 2008. Overconfidence, CEO selection, and corporate governance. Journal of Finance 63, 2737-2784.

Hirshleifer, D., Low, A., Teoh, S.H., 2012. Are overconfident CEOs better innovators? Journal of Finance 67, 1457-1498.

Holmstrom, B., Costa, J.R.I., 1986. Managerial incentives and capital management. Quarterly Journal of Economics 101, 835-860.

Hong, H., Lim, T., Stein, J., 2000. Bad news travels slowly: Size, analyst coverage, and the profitability of momentum strategies. Journal of Finance 55, 265-295.

Hubbard, T.D., Christensen, D.M., Graffin, S.D., 2017. Higher highs and lower lows: The role of corporate social responsibility in CEO dismissal. Strategic Management Journal 38, 22552265 .

Kacperczyk, A., 2009. With greater power comes greater responsibility? Takeover protection and corporate attention to stakeholders. Strategic Management Journal 30, 261-285.

Kang, J., 2016. Labor market evaluation versus legacy conservation: What factors determine retiring CEOs' decisions about long-term investment? Strategic Management Journal 37, 389405.

Kaplan, S.N., Reishus, D., 1990. Outside directorships and corporate performance. Journal of Financial Economics 27, 389-410. 
Kedia, S., Rajgopal, S., 2009. Neighborhood matters: The impact of location on broad-based stock option plans. Journal of Financial Economics 92, 109-127.

Kitzmueller, M., Shimshack, J., 2012. Economic perspectives on corporate social responsibility. Journal of Economic Literature 50, 51-84.

Knyazeva, A, Knyazeva, D., Masulis, R.W., 2013. The supply of corporate directors and board independence. Review of Financial Studies 26, 1561-1605.

Kruger, P., 2015. Corporate goodness and shareholder wealth. Journal of Financial Economics 115, 304-329.

Lazear, E.P., 2009. Firm-specific human capital: a skill-weights approach. Journal of Political Economy 117, 914-940.

Lev, B., 2004. Sharpening the intangibles edge. Harvard Business Review 82, 109-116.

Lev, B., Sougiannis, T., 1996. The capitalization, amortization, and value-relevance of RD. Journal of Accounting and Economics 21, 107-138.

Liang, H., Renneboog, L., 2017. On the foundations of corporate social responsibility. Journal of Finance 72, 853-910.

Lins, K.V., Servaes, H., Tamayo, A., 2017. Social capital, trust, and firm performance: the value of corporate social responsibility during the financial crisis. Journal of Finance 72, 17851823.

Manner, M.H., 2010. The impact of CEO characteristics on corporate social performance. Journal of Business Ethics 93, 53-72.

May, D.O., 1995. Do managerial motives influence firm risk reduction strategies. Journal of Finance 50, 1291-1308.

McCarthy, S., Oliver, B., Song, S., 2017. Corporate social responsibility and CEO confidence. Journal of Banking \& Finance 75, 280-291.

McGuire, J., Dow, S., Argheyd, K., 2003. CEO incentives and corporate social performance. Journal of Business Ethics 45, 341-359.

McWilliams, A., Siegel, D., 2001. Corporate social responsibility: A theory of the firm perspective. Academy of Management Review 26, 117-127.

Miller, D., 1991. Stale in the saddle: CEO tenure and the match between organization and environment. Management Science 37, 34-52.

Mishra, D.R., 2014. The dark side of CEO ability: CEO general managerial skills and cost of equity capital. Journal of Corporate Finance 29, 390-409.

Mosley, D., Pietri, P.H., Megginson L.C., 1996. Management: Leadership in Action. Harper Collins, New York. 
Murphy, K.J., Zabojnik, J., 2007. Managerial capital and the market for CEOs. Unpublished working paper. University of South California.

Narayanan, M.P., 1985. Managerial incentives for short-term results. Journal of Finance 40, $1469-1484$.

Ogden, S., Watson, R., 1999. Corporate performance and stakeholder management: Balancing shareholder and customer interests in the UK privatized water industry. Academy of Management Journal 42, 526-538.

Oh, W.Y., Chang, Y., Cheng, Z., 2016. When CEO career horizon problems matter for corporate social responsibility: The moderating roles of industry-level discretion and blockholder ownership. Journal of Business Ethics 133, 279-291.

Rao, K., Tilt, C., 2016. Board composition and corporate social responsibility: The role of diversity, gender, strategy and decision making. Journal of Business Ethics 138, 327-347.

Schoar, A., Zuo, L., 2017. Shaped by booms and busts: How the economy impacts CEO careers and management styles. Review of Financial Studies 30, 1425-1456.

Stein, J.C., 1989. Efficient capital markets, inefficient firms: A model of myopic corporate behaviour. Quarterly Journal of Economics 104, 655-669.

Tang, Y., Qian, C.L., Chen, G.L., Shen, R., 2015. How CEO hubris affects corporate social (ir)responsibility. Strategic Management Journal 36, 1338-1357.

Thomas, D., Ely, R., 1996. Making difference matters: A new paradigm for managing diversity. Harvard Business Review 74, 79-90.

Whetten, D.A., Mackey, A., 2002. Identity congruence and its implications for the study of organizational reputation. Business and Society 41, 393-414.

Xuan, Y.H., 2009. Empire-building or bridge-building? Evidence from new CEOs' internal capital allocation decisions. Review of Financial Studies 22, 4919-4948.

Yonker, S.E., 2017. Geography and the Market for CEO. Management Science 63, 609-630.

Zadek, S., 2004. The path to corporate responsibility. Harvard Business Review 82, 125-132. 


\section{Table 1}

\section{Summary statistics}

This table presents the number of observations and the mean, median, standard deviation, minimum, and maximum for each variable. The sample consists of 10, 750 firm-year observations between 1996 and 2012. Variable definitions are provided in the Appendix.

\begin{tabular}{lcccccc}
\hline Variable & Obs. & Mean & Median & St.Dev. & Minimum & Maximum \\
\hline CSR & 10,750 & -0.213 & -0.200 & 0.646 & -3.250 & 7.167 \\
General Ability Index & 10,750 & 0.043 & -0.129 & 0.984 & -1.847 & 7.230 \\
CEO age & 10,750 & 55.290 & 56.000 & 7.468 & 32.000 & 94.000 \\
CEO tenure & 10,750 & 8.010 & 6.000 & 7.296 & 1.000 & 60.000 \\
CEO gender & 10,750 & 0.019 & 0.000 & 0.138 & 0.000 & 1.000 \\
CEO duality & 10,750 & 0.664 & 1.000 & 0.472 & 0.000 & 1.000 \\
CEO MBA & 10,750 & 0.332 & 0.000 & 0.471 & 0.000 & 1.000 \\
CEO Ivy league & 10,750 & 0.188 & 0.000 & 0.391 & 0.000 & 1.000 \\
CEO military & 10,750 & 0.069 & 0.000 & 0.254 & 0.000 & 1.000 \\
CEO fast track & 10,750 & 46.291 & 47.000 & 7.571 & 19.000 & 72.000 \\
Sales (\$ millions) & 10,750 & 6388.2 & 1841.0 & 13048.1 & 71.5 & 89131.0 \\
ROA & 10,750 & 0.137 & 0.130 & 0.088 & -0.117 & 0.420 \\
Stock return & 10,750 & 0.135 & 0.097 & 0.439 & -0.728 & 2.020 \\
Leverage & 10,750 & 0.213 & 0.205 & 0.166 & 0.000 & 0.812 \\
Tobin's Q & 10,750 & 1.946 & 1.531 & 1.218 & 0.820 & 7.776 \\
Asset tangibility & 10,750 & 0.269 & 0.203 & 0.229 & 0.001 & 0.878 \\
Firm age & 10,750 & 27.148 & 21.000 & 19.882 & 1.000 & 84.000 \\
Board independence & 10,750 & 0.719 & 0.750 & 0.160 & 0.000 & 1.000 \\
Board busyness & 10,750 & 0.271 & 0.222 & 0.246 & 0.000 & 1.000 \\
Institutional ownership & 10,750 & 0.762 & 0.783 & 0.178 & 0.204 & 1.000 \\
\hline
\end{tabular}


Table 2

Univariate analysis

This table presents the univariate analysis results for firm and CEO characteristics. Panel A compares the characteristics of firms run by generalist CEOs and those by specialist CEOs at the firm-year level. We classify CEOs with a general ability index above the yearly median as generalists and those with an index below the yearly median as specialists. Panel B compares the personal characteristics of generalist CEOs and those of specialist CEOs at the CEO level. There are 2744 unique CEOs in our sample. For each CEO, we calculate an average general ability index across all years in the sample. We then classify them into the generalist and specialist groups based on the median of the average general ability index. The personal characteristic variables are aggregated to the CEO level by taking averages over years before conducting the univariate analysis. All variables are defined in the Appendix. t-tests (Wilcoxon-Mann-Whitney tests) are conducted to test for differences in the means (medians). $* * *, * *$, and $*$ indicate significance at the $1 \%, 5 \%$, and $10 \%$ levels, respectively.

Panel A. Univariate analysis of firm characteristics at the firm-year level

\begin{tabular}{lcccccc}
\hline \multirow{2}{*}{ Variable } & \multicolumn{2}{c}{ Generalist CEOs } & \multicolumn{2}{c}{ Specialist CEOs } & \multirow{2}{*}{ Test of difference } \\
\cline { 2 - 7 } & Mean & Median & Mean & Median & Mean & Median \\
\hline CSR & -0.246 & -0.209 & -0.179 & -0.164 & $-0.067^{* * *}$ & $-0.045^{* * *}$ \\
Sales (\$ millions) & 8382.6 & 2512.0 & 4316.6 & 1379.4 & $4066.0^{* * *}$ & $1132.6^{* * *}$ \\
ROA & 0.136 & 0.129 & 0.137 & 0.132 & -0.001 & -0.003 \\
Stock return & 0.129 & 0.095 & 0.141 & 0.098 & $-0.012^{*}$ & -0.003 \\
Leverage & 0.229 & 0.224 & 0.197 & 0.185 & $0.032^{* * *}$ & $0.039^{* * *}$ \\
Tobin's Q & 1.933 & 1.528 & 1.960 & 1.534 & -0.027 & -0.006 \\
Asset tangibility & 0.276 & 0.212 & 0.263 & 0.191 & $0.013^{* * *}$ & $0.021^{* * *}$ \\
Firm age & 29.178 & 23.000 & 25.038 & 20.000 & $4.140^{* * *}$ & $3.000^{* * * *}$ \\
Board independence & 0.738 & 0.778 & 0.699 & 0.714 & $0.039^{* * *}$ & $0.064^{* * *}$ \\
Board busyness & 0.317 & 0.286 & 0.223 & 0.167 & $0.094^{* * *}$ & $0.119^{* * *}$ \\
Institutional ownership & 0.772 & 0.794 & 0.751 & 0.771 & $0.021^{* * *}$ & $0.023^{* * * *}$ \\
\hline
\end{tabular}

Panel B. Univariate analysis of CEO characteristics at the CEO level

\begin{tabular}{|c|c|c|c|c|c|c|}
\hline \multirow{2}{*}{ Variable } & \multicolumn{2}{|c|}{$\begin{array}{c}\text { Generalist CEOs } \\
N=1235\end{array}$} & \multicolumn{2}{|c|}{$\begin{array}{c}\text { Specialist CEOs } \\
N=1509\end{array}$} & \multicolumn{2}{|c|}{ Test of difference } \\
\hline & Mean & Median & Mean & Median & Mean & Median \\
\hline CEO age & 56.020 & 56.000 & 54.510 & 54.600 & $1.510 * * *$ & $1.400 * * *$ \\
\hline CEO tenure & 5.863 & 4.000 & 8.003 & 5.000 & $-2.141 * * *$ & $-1.000 * * *$ \\
\hline CEO gender & 0.032 & 0.000 & 0.019 & 0.000 & $0.013^{* *}$ & $0.000 * *$ \\
\hline CEO duality & 0.665 & 1.000 & 0.599 & 1.000 & $0.066 * * *$ & $0.000 * * *$ \\
\hline CEO MBA & 0.381 & 0.000 & 0.287 & 0.000 & $0.094 * * *$ & $0.000 * * *$ \\
\hline CEO Ivy league & 0.227 & 0.000 & 0.143 & 0.000 & $0.084 * * *$ & $0.000 * * *$ \\
\hline CEO military & 0.089 & 0.000 & 0.050 & 0.000 & $0.039 * * *$ & $0.000 * * *$ \\
\hline CEO fast track & 48.058 & 48.000 & 46.033 & 47.000 & $2.025 * * *$ & $1.000 * * *$ \\
\hline
\end{tabular}




\section{Table 3}

\section{General managerial ability and CSR}

This table examines the effect of General Ability Index on CSR. General Ability Index_dummy is an indicator variable that equals one if a firm's General Ability Index is above the yearly median and zero otherwise. Panel A presents OLS regression results and Panel B presents regression results using alternative modelling techniques. Industry effects are constructed based on the Fama-French 49-industry classification. Variable definitions are provided in the Appendix. Statistical significance is based on the heteroscedasticity-robust firm-clustered standard errors reported in parentheses. $* * *, * *$, and $*$ indicate significance at the $1 \%, 5 \%$, and $10 \%$ levels, respectively.

Panel A. OLS regression results

Variable

General Ability Index $\mathrm{t}_{-1}$

General Ability Index_dummyt-1

CEO age t- $_{1}$

CEO tenure t-1 $_{1}$

CEO gender ${ }_{t-1}$

CEO duality t-1

CEO MBA $\mathrm{M}_{\mathrm{t}-1}$

CEO Ivy league ${ }_{t-1}$

CEO military $\mathrm{t}_{-1}$

CEO fast track $\mathrm{t}_{\mathrm{t}-1}$

$\operatorname{Ln}(\text { Sales })_{\mathrm{t}-1}$

Dependent variable: $C S R$ (1)

$-0.035 * * *$

(0.011)

(2)

$\begin{array}{cc}(1) & (2) \\ -0.035 * * * & - \\ (0.011) & -0.059 * * * \\ - & (0.022) \\ -0.001 & -0.001 \\ (0.002) & (0.002) \\ -0.003 & -0.003 \\ (0.002) & (0.002) \\ 0.529 * * * & 0.509 * * * \\ (0.081) & (0.081) \\ 0.023 & 0.023 \\ (0.023) & (0.023) \\ 0.028 & 0.033 \\ (0.025) & (0.025) \\ 0.066 * * & 0.063 * * \\ (0.029) & (0.029) \\ 0.034 & 0.030 \\ (0.047) & (0.048) \\ -0.002 & -0.001 \\ (0.002) & (0.002) \\ 0.052 & 0.038\end{array}$


$\mathrm{ROA}_{\mathrm{t}-1}$

(0.032)

(0.031)

$0.632 * * *$

$0.600 * * *$

Stock return $n_{\mathrm{t}-1}$

(0.157)

(0.156)

$-0.011$

$-0.021$

(0.014)

(0.014)

Leverage $_{\mathrm{t}-1}$

$-0.033$

0.040

(0.080)

(0.082)

Tobin's $\mathrm{Q}_{\mathrm{t}-1}$

$-0.005$

0.004

(0.011)

(0.011)

Asset tangibility $\mathrm{t}-1$

$-0.165^{* *}$

$-0.292 * * *$

(0.067)

(0.067)

$-0.001$

$-0.001$

Firm age $_{t-1}$

(0.001)

(0.001)

Board independence ${ }_{t-1}$

$0.172 * * *$

$0.126^{* * * *}$

$(0.062)$

(0.061)

Board busynesst-1

0.066

0.063

(0.043)

(0.043)

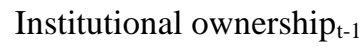

$-0.187 * *$

$-0.248 * * *$

(0.073)

Industry effects

Yes

Year effects

Yes

(0.076)

$\mathrm{N}$

10,750

Yes

Adjusted $\mathrm{R}^{2}$

0.088

10,750

0.082 
Panel B. Alternative modelling techniques

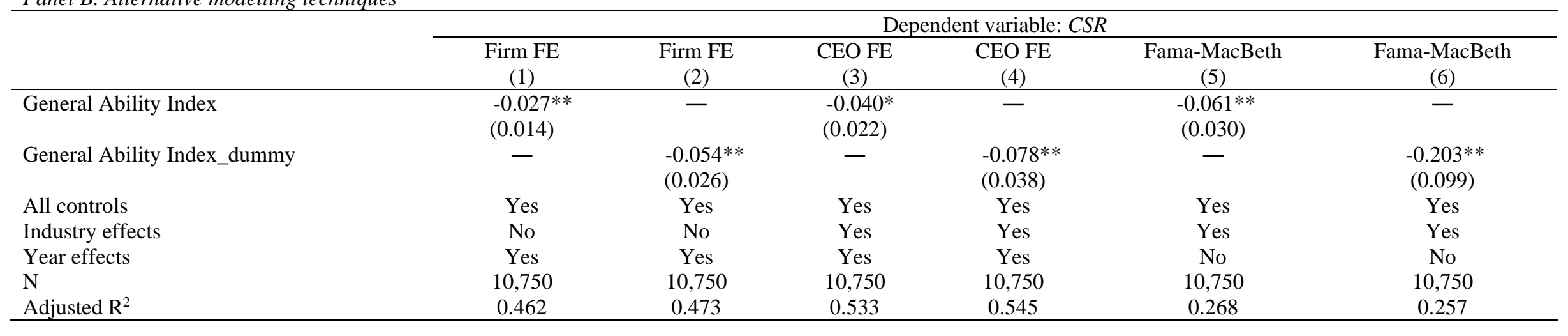


Table 4

Propensity score matching estimates

Table 4 presents the propensity score matching estimation results. Panel A reports the parameter estimates from the logit model used to estimate the propensity scores. The dependent variable is an indicator variable for the presence of generalist CEOs in a firm for a given year. All independent variables are defined in the Appendix. Industry effects are constructed based on the Fama-French 49-industry classification. Statistical significance is based on the heteroscedasticity-robust firm-clustered standard errors reported in parentheses. Panel B shows the univariate comparisons of firm characteristics between firms with and without generalist CEOs and the corresponding $\mathrm{t}$-statistics. Panel $\mathrm{C}$ shows the average treatment effect estimates. The variable CSR is the rating of corporate social responsibilities. $* * *, * *$, and $*$ indicate significance at the $1 \%, 5 \%$, and $10 \%$ levels, respectively.

\begin{tabular}{|c|c|c|}
\hline \multirow[b]{2}{*}{ Variables } & \multicolumn{2}{|c|}{$\begin{array}{c}\text { Dependent variable: } \\
\text { Dummy equals } 1 \text { for firms run by generalist CEOs and } 0 \text { otherwise }\end{array}$} \\
\hline & Pre-match & Post-match \\
\hline CEO age & $\begin{array}{c}0.059 * * * \\
(0.012)\end{array}$ & $\begin{array}{c}0.006 \\
(0.011)\end{array}$ \\
\hline CEO tenure & $\begin{array}{c}-0.063 * * * \\
(0.012)\end{array}$ & $\begin{array}{l}-0.004 \\
(0.011)\end{array}$ \\
\hline CEO gender & $\begin{array}{c}0.800^{* * *} \\
(0.296)\end{array}$ & $\begin{array}{c}0.115 \\
(0.315)\end{array}$ \\
\hline CEO duality & $\begin{array}{c}0.147 \\
(0.107)\end{array}$ & $\begin{array}{l}-0.035 \\
(0.109)\end{array}$ \\
\hline CEO MBA & $\begin{array}{c}0.332 * * * \\
(0.107)\end{array}$ & $\begin{array}{l}0.027 \\
(0.111)\end{array}$ \\
\hline CEO Ivy league & $\begin{array}{c}0.451 * * * \\
(0.136)\end{array}$ & $\begin{array}{c}0.016 \\
(0.142)\end{array}$ \\
\hline CEO military & $\begin{array}{l}0.325^{*} \\
(0.184)\end{array}$ & $\begin{array}{l}-0.047 \\
(0.201)\end{array}$ \\
\hline CEO fast track & $\begin{array}{l}-0.015 \\
(0.011)\end{array}$ & $\begin{array}{l}-0.007 \\
(0.010)\end{array}$ \\
\hline Ln(Sales) & $\begin{array}{c}0.610^{* * * *} \\
(0.095)\end{array}$ & $\begin{array}{l}-0.015 \\
(0.099)\end{array}$ \\
\hline ROA & $\begin{array}{l}-0.594 \\
(0.555)\end{array}$ & $\begin{array}{c}0.144 \\
(0.583)\end{array}$ \\
\hline Stock return & $\begin{array}{l}-0.062 \\
(0.051)\end{array}$ & $\begin{array}{c}0.013 \\
(0.057)\end{array}$ \\
\hline Leverage & $\begin{array}{c}0.272 \\
(0.302)\end{array}$ & $\begin{array}{c}0.059 \\
(0.314)\end{array}$ \\
\hline Tobin's Q & $\begin{array}{l}0.071^{*} \\
(0.043)\end{array}$ & $\begin{array}{l}-0.014 \\
(0.044)\end{array}$ \\
\hline Asset tangibility & $\begin{array}{l}-0.301 \\
(0.267)\end{array}$ & $\begin{array}{l}-0.022 \\
(0.281)\end{array}$ \\
\hline Firm age & $\begin{array}{c}-0.005^{*} \\
(0.003)\end{array}$ & $\begin{array}{c}0.001 \\
(0.003)\end{array}$ \\
\hline Board independence & $\begin{array}{c}0.801 * * * \\
(0.260)\end{array}$ & $\begin{array}{l}-0.015 \\
(0.274)\end{array}$ \\
\hline Board busyness & $\begin{array}{c}0.916 * * * \\
(0.171)\end{array}$ & $\begin{array}{l}-0.026 \\
(0.174)\end{array}$ \\
\hline
\end{tabular}




\begin{tabular}{|c|c|c|c|c|}
\hline Institutional ownership & & $\begin{array}{c}1.299 * * * \\
(0.254) \\
\end{array}$ & & $\begin{array}{c}-0.062 \\
(0.271) \\
\end{array}$ \\
\hline Industry effects & & Yes & & Yes \\
\hline Year effects & & Yes & & Yes \\
\hline $\mathrm{N}$ & & 10,750 & & 7,174 \\
\hline Pseudo-R ${ }^{2}$ & & 0.118 & & 0.002 \\
\hline \multicolumn{5}{|c|}{ Panel B. Differences in CEO and firm characteristics } \\
\hline Variables & $\begin{array}{c}\text { Firm-year obs. } \\
\text { with generalist CEOs } \\
(\mathrm{N}=3587)\end{array}$ & $\begin{array}{c}\text { Firm-year obs. } \\
\text { with specialist CEOs } \\
(\mathrm{N}=3587)\end{array}$ & Difference & t-stat \\
\hline CEO age & 55.195 & 55.149 & 0.046 & 0.278 \\
\hline CEO tenure & 7.561 & 7.546 & 0.015 & 0.094 \\
\hline CEO gender & 0.020 & 0.017 & 0.003 & 0.907 \\
\hline CEO duality & 0.652 & 0.663 & -0.011 & -0.947 \\
\hline CEO MBA & 0.340 & 0.329 & 0.011 & 0.975 \\
\hline CEO Ivy league & 0.174 & 0.170 & 0.004 & 0.453 \\
\hline CEO military & 0.060 & 0.062 & -0.002 & -0.412 \\
\hline CEO fast track & 46.543 & 46.629 & -0.086 & -0.489 \\
\hline $\operatorname{Ln}($ Sales $)$ & 6.293 & 6.297 & -0.004 & -0.286 \\
\hline ROA & 0.139 & 0.138 & 0.001 & 0.369 \\
\hline Stock return & 0.139 & 0.137 & 0.002 & 0.223 \\
\hline Leverage & 0.212 & 0.211 & 0.001 & 0.276 \\
\hline Tobin's Q & 1.958 & 1.964 & -0.006 & -0.209 \\
\hline Asset tangibility & 0.266 & 0.269 & -0.003 & -0.487 \\
\hline Firm age & 26.863 & 27.000 & -0.137 & -0.292 \\
\hline Board independence & 0.721 & 0.722 & -0.001 & -0.066 \\
\hline Board busyness & 0.266 & 0.269 & -0.003 & -0.474 \\
\hline Institutional ownership & 0.772 & 0.770 & 0.002 & 0.567 \\
\hline \multicolumn{5}{|c|}{ Panel C. Propensity score matching estimate } \\
\hline Variables & $\begin{array}{c}\text { Firm-year obs. } \\
\text { with generalist CEOs } \\
(\mathrm{N}=3587)\end{array}$ & $\begin{array}{c}\text { Firm-year obs. } \\
\text { with specialist CEOs } \\
(\mathrm{N}=3587)\end{array}$ & Difference & t-stat \\
\hline CSR & -0.212 & -0.163 & $-0.049 * * *$ & -3.330 \\
\hline
\end{tabular}




\section{Table 5}

Instrumental variables estimates

This table presents estimates of the instrumental variables method using two-stage least square (2SLS) panel regression. The dependent variable is General Ability Index for the first-stage regression and CSR for the second-stage regression. The instrumental variable is Recession depth. Following Schoar and Zuo (2017), we identify whether there was a recession in the year when the CEO started his or her career, based on the NBER business cycle dating database. The variable Recession depth is then defined as the number of months the recession lasted if there was a recession and zero otherwise. The other control variables are the same as in column (3) of Table 3. For the sake of brevity, we report only the coefficients of the main variables of interest. Industry and year fixed effects are included. Industry effects are constructed based on the Fama-French 49-industry classification. Statistical significance is based on the heteroscedasticity-robust firm-clustered standard errors reported in parentheses. ***, **, and * indicate significance at the $1 \%, 5 \%$, and $10 \%$ levels, respectively.

\begin{tabular}{lcc}
\hline & $\begin{array}{c}\text { Dependent variable: } \\
\text { General Ability Index }\end{array}$ & $\begin{array}{c}\text { Dependent variable: } \\
\text { CSR }\end{array}$ \\
\cline { 2 - 3 } Variables & First Stage & Second stage \\
& $(1)$ & - \\
\hline Recession depth & $-0.015^{* * *}$ & \\
& $(0.004)$ & $-0.553^{* *}$ \\
General Ability Index $\mathrm{t}_{-1}$ & - & $(0.258)$ \\
\hline Controls & & Yes \\
Industry effects & Yes & Yes \\
Year effects & Yes & Yes \\
$\mathrm{N}$ & Yes & 10,750 \\
F-statistic & 10,750 & \\
\hline
\end{tabular}


Table 6

\section{Effect of local labor market tightness}

This table examines whether the relation between general managerial skills and CSR activity is affected by the tightness of the local labor market. We measure the tightness of the local labor market by the state-level unemployment rate obtained from the Bureau of Labor Statistics. We then split the sample into high- and low-tightness groups based on the state-level unemployment rates. A state is in the high-tightness (low-tightness) group if it has an unemployment rate that is below (above) the sample median across all states in a given year. The p-value row presents the p-values of the test that the coefficients in the high and low columns are equal. Industry effects are constructed based on the Fama-French 49-industry classification. Variable definitions are provided in the Appendix. Statistical significance is based on the heteroscedasticity-robust firm-clustered standard errors reported in parentheses. ***, **, and * indicate significance at the $1 \%, 5 \%$, and $10 \%$ levels, respectively.

\begin{tabular}{lcc}
\hline & \multicolumn{2}{c}{ OLS regressions } \\
Variables & \multicolumn{2}{c}{ Dependent variable: $C S R$} \\
\cline { 2 - 3 } & High tightness & Low tightness \\
& $(1)$ & $(2)$ \\
\hline General ability index $\mathrm{x}_{\mathrm{t}}$ & $-0.049^{* *}$ & -0.014 \\
& $(0.020)$ & $(0.012)$ \\
\hline Controls & Yes & Yes \\
Industry effects & Yes & Yes \\
Year effects & Yes & Yes \\
p-value & 0.067 & 0.067 \\
$\mathrm{~N}$ & 6,492 & 4,258 \\
Adjusted $\mathrm{R}^{2}$ & 0.091 & 0.084 \\
\hline
\end{tabular}




\section{Table 7}

\section{Effect of the investor horizon}

This table examines whether the relation between general managerial skills and CSR activity is affected by the investor horizon, Investor turnover. The Investor turnover value of a firm is the average turnover of its investors' entire portfolios, with higher values indicating shorter horizons. We split the sample into high- and low-turnover groups based on the sample median of Investor turnover. The p-value row presents the p-values of the test that the coefficients in the high and low columns are equal. Industry effects are constructed based on the Fama-French 49-industry classification. Variable definitions are provided in the Appendix. Statistical significance is based on the heteroscedasticity-robust firm-clustered standard errors reported in parentheses. ***, **, and * indicate significance at the $1 \%, 5 \%$, and $10 \%$ levels, respectively.

\begin{tabular}{lcc}
\hline \multirow{2}{*}{ Variables } & \multicolumn{2}{c}{ OLS regressions } \\
& \multicolumn{2}{c}{ Dependent variable: CSR } \\
\cline { 2 - 3 } & High investor turnover & Low investor turnover \\
GAI Ability Index $\mathrm{t}_{-1}$ & $(1)$ & $(2)$ \\
\hline Controls & $-0.039^{* * *}$ & -0.011 \\
Industry effects & $(0.017)$ & $(0.014)$ \\
Year effects & Yes & Yes \\
p-value & Yes & Yes \\
$\mathrm{N}$ & Yes & Yes \\
Adjusted $\mathrm{R}^{2}$ & 0.074 & 0.074 \\
& 5,702 & 5,048 \\
\end{tabular}




\section{Table 8}

\section{Robustness tests}

This table contains a number of checks testing the robustness of the relation between general managerial skills and CSR to alternative CSR measures, model specifications, clustering, and definitions of industry dummies. We include the same set of control variables and industry and year fixed effects as in our baseline regressions. For brevity, we report only the coefficients of the general managerial ability variables, unless otherwise specified. The p-value row presents the p-value of the test that the coefficients of Specialist to generalist and Generalist to specialist are equal. Statistical significance is based on the heteroscedasticity-robust firm-clustered standard errors reported in parentheses. $* * *, * *$, and $*$ indicate significance at the $1 \%, 5 \%$, and $10 \%$ levels, respectively.

OLS regressions

Dependent variable: $\triangle C S R$

\section{Panel A: Switch of CEO type (N=683)}

Specialist to generalist

$-0.181 * * *$

$(0.031)$

$0.038 *$

Generalist to specialist

$(0.021)$

$36.70 * * *$

F-test: Specialist to generalist vs. Generalist to specialist

OLS regressions

Dependent variable: $C S R$

$\begin{array}{cc}\text { General Ability } & \text { General Ability } \\ \text { Index } & \text { Index_dummy }\end{array}$

(1)

(2)

Panel B: Alternative measures of CSR

CSR_Net

$-0.168 * * *$

$-0.276 * * *$

CSR_Five

$(0.058)$

(0.103)

CSR_Five

$-0.024 * *$

$-0.045^{* *}$

CSR_Net_Five

(0.011)

(0.019)

$-0.113 * *$

$-0.195 * *$

Panel C: Alternative model specifications

(0.054)

Controlling for $R \& D$ expenditure/TA

$-0.036^{* * * *}$

$-0.068 * * *$

(0.012)

$(0.022)$

Controlling for Cost of capital

$-0.034 * * *$

$-0.061 * * *$

(0.012)

$(0.023)$

Controlling for $\ln$ (CEO total compensation)

$-0.025 * *$

$-0.047 * *$

(0.012)

$(0.022)$

Controlling for $\ln (1+C E O$ delta $)$ and $\ln (1+C E O$ vega $)$

$-0.036 * * *$

$-0.068 * * *$

(0.013)

$(0.022)$

Controlling for $C E O$ confidence

$-0.033 * * *$

$-0.059^{* * *}$

(0.012)

$(0.022)$

Panel D: Alternative clustering and definitions of industry dummies

Clustering by year

Clustering by industry

Two-digit SIC industry dummies

Three-digit NAICS industry dummies

$\begin{array}{ll}-0.033 * * * & -0.059 * * * \\ (0.008) & (0.013) \\ -0.035 * * & -0.057 * * \\ (0.017) & (0.026) \\ -0.033 * * & -0.060 * * \\ (0.016) & (0.028) \\ -0.032 * * & -0.059 * * \\ (0.014) & (0.027)\end{array}$




\section{Appendix}

Variable definitions

\begin{tabular}{l} 
Variable \\
\hline Panel A: Main variables
\end{tabular}

\section{CSR}

General Ability Index

General Ability Index_dummy

Panel B: Firm characteristics

\section{Ln(Sales)}

\section{ROA}

Stock return

Leverage

Tobin's Q

Firm age
Asset tangibility
Description

Modified CSR score constructed following Deng et al. (2013) and Lins et al. (2017).

Index of general managerial ability developed by Custódio et al. (2013) that incorporates five

aspects of a CEO's lifetime career experience, including the past number of (i) positions, (ii)

firms, and (iii) industries in which the CEO worked; (iv) whether the CEO held a CEO position at

a different company; and (v) whether the CEO worked for a conglomerate firm. The index is the

first factor of the principal component analysis of the five proxies.

Indicator variable that takes the value of one if the CEO has a general ability index that is above the yearly median and zero otherwise.

Natural logarithm of firm sales.

Earnings before interest, taxes, depreciation, and amortization, divided by total assets.

Firm's stock return over the past year.

Sum of short- and long-term debt, divided by total assets.

Market value of equity plus the book value of total assets minus the book value of equity, all

divided by total assets, where the market value of equity is the year-end closing price times the number of shares outstanding.

Total value of property, plant, and equipment, divided by total assets.

Number of years since the firm listed its shares.
Source

KLD

BoardEx

BoardEx

Compustat

Compustat

CRSP

Compustat

Compustat

Compustat

CRSP

IRRC/RiskMetrics IRRC/RiskMetrics

Board independence

The fraction of independent directors on the board.

Board busyness

The fraction of independent directors with multiple directorships on the board.

Institutional ownership
Thomson

CDA/Spectrum 
Dummy variable that equals one if a CEO is female and zero otherwise.

CEO MBA

Dummy variable that equals one if a CEO is also the chair of the board and zero otherwise.

Dummy variable that equals one if a CEO has an MBA and zero otherwise.

BoardEx

Dummy variable that equals one if a CEO attended an Ivy League university (i.e., Brown

BoardEx

CEO Ivy league

University, Columbia University, Cornell University, Dartmouth College, Harvard University,

Princeton University, University of Pennsylvania, and Yale University) at any academic level and zero otherwise.

CEO military

A dummy variable that equals one if a CEO has military experience and zero otherwise.

BoardEx

BoardEx

\section{CEO fast track}

Age at which a CEO became CEO for the first time.

BoardEx

BoardEx

Panel E: Variables used in further analysis and robustness tests

Specialist to generalist

Generalist to specialist

CSR Net

CSR_Five

\section{CSR Net_Five}

\section{R\&D expenditure/TA}

Cost of capital

Ln(CEO total compensation)

$\operatorname{Ln}(1+\mathrm{CEO}$ delta $)$

$\operatorname{Ln}(1+\mathrm{CEO}$ vega $)$
Dummy variable that equals one if there is a specialist CEO at year $\mathrm{t}-1$ replaced by a generalist $\mathrm{CEO}$ at year $\mathrm{t}$.

Dummy variable that equals one if there is a generalist CEO at year $\mathrm{t}-1$ replaced by a specialist $\mathrm{CEO}$ at year $\mathrm{t}$.

The sum value of a score form the total number of strengths minus the total number of concerns. Modified CSR score constructed following Deng et al. (2013) and Lins et al. (2017), which includes community, diversity, employee relations, environment, and product quality.

The sum value of a score form the total number of strengths minus the total number of concerns, which includes community, diversity, employee relations, environment, and product quality.

Expenditures on R\&D divided by total assets.

Following Dhaliwal et al. (2011), the cost of capital is calculated as the mean value of the three cost of capital measures developed by Gebhardt et al. (2001), Claus and Thomas (2001), and Easton (2004), respectively.

The natural logrithm value of CEO total compensation, which consists of salary, bonus, value of restricted stock granted, value of options granted, long-term incentive payout, and other compensation.

The natural logrithm value of one plus CEO delta, which is the dollar change in wealth associated with a $1 \%$ change in the firm's stock price.

The natural logrithm value of one plus CEO vega, which is the dollar change in wealth associated with a $1 \%$ change in the standard deviation of the firm's returns.

\section{BoardEx}

BoardEx

KLD

KLD

Compustat

I/B/E/S, Compustat

\section{EXECUCOMP}

Personal website of Lalitha Naveen Personal website of Lalitha Naveen 
A measure of the extent to which stock price exceeds the exercise price. Following Campbell et al. (2011) and Hirshleifer et al. (2012), we first calculate the average realizable value per option by dividing the total realizable value of exercisable options by the number of exercisable options. We then subtract the average realizable value from the fiscal year-end stock price to obtain the average exercise price of the options. Finally, the estimated moneyness of the options is calculated as the stock price divided by the estimated average exercise price minus one.
Execucomp,

Compustat 
Supporting Documentation for Manuscript

"General managerial skills and corporate social responsibility"

NOT FOR PUBLICATION

Results Available From the Authors on Request 


\section{Table A1}

\section{Effect of the CEOs' outside options}

This table examines whether the relation between general managerial skills and CSR activity is affected by the value of the CEO's outside options. Following Custódio et al. (2017) and Kedia and Rajgopal (2009), we use two measures of labor market conditions to capture the variation in the value of outside options. The first measure is the tightness of the local labor market.We measure the tightness of the local labor market by the state-level unemployment rate obtained from the Bureau of Labor Statistics. The second measure is the local beta, which shows the degree of co-movement between a firm's stock return and stock returns of other firms that are in the same region. In columns (1) and (2), we split the sample into high- and low-tightness groups based on the statelevel unemployment rates. A state is in the high-tightness (low-tightness) group if it has an unemployment rate that is below (above) the sample median across all states in a given year. In columns (3) and (4), we calculate the local beta following Kedia and Rajgopal (2009) and split the sample into high- and low-local beta firms. A firm is classified to have a high (low) local beta if its beta is above (below) the median value of beta of other firms in the same state in a given year. The p-value row presents the p-values of the test that the coefficients in the high and low columns are equal. Industry effects are constructed based on the Fama-French 49-industry classification. Variable definitions are provided in the Appendix. Statistical significance is based on the heteroscedasticity-robust firm-clustered standard errors reported in parentheses. ***, **, and * indicate significance at the $1 \%, 5 \%$, and $10 \%$ levels, respectively.

\begin{tabular}{lcc}
\hline & \multicolumn{2}{c}{ OLS regressions } \\
& \multicolumn{2}{c}{ Dependent variable: CSR } \\
\cline { 2 - 3 } & High local beta & Low local beta \\
& $(1)$ & $(2)$ \\
\hline \multirow{2}{*}{ GAI Ability Index $\mathrm{t}-1$} & $-0.053^{* *}$ & $-0.021^{*}$ \\
& $(0.022)$ & $(0.013)$ \\
\hline Controls & Yes & Yes \\
Industry effects & Yes & Yes \\
Year effects & Yes & 0.182 \\
p-value & 0.182 & 4,453 \\
$\mathrm{~N}$ & 5,389 & 0.083 \\
Adjusted $\mathrm{R}^{2}$ & 0.086 & \\
\hline
\end{tabular}

